\title{
Precedent Onyms in Religious Phraseological Units in the Spanish Language (On the Transition from the Phraseological Units with Precedent Onyms to the Precedent Phenomenon)
}

\author{
Aliyeva Rena Mirzababa ${ }^{1}$ \\ ${ }^{1}$ Department of Spanish Translation, Azerbaijan University of Languages, Baku, Azerbaijan \\ Correspondences: Aliyeva Rena Mirzababa, Department of Spanish Translation, Azerbaijan University of \\ Languages, Baku, Azerbaijan. E-mail: shalalahaliyevah@yahoo.com or aliyeva_rena@hotmail.com
}

Received: November 10, 2017 Accepted: December 3, 2017 Online Published: February 4, 2018

doi:10.5539/ijel.v8n3p186 URL: http://doi.org/10.5539/ijel.v8n3p186

\begin{abstract}
The article deals with the matter of precedent onyms in religios phraseological units in the Spanish language. The task of the given article is to look through the samples on the given phenomenon.

Religious phraseological units in the Spanish language are analyzed from lexical and componential points of view.

The linguistic or the semantic aspect of cognitivism, i.e. the mental identity of a native speaker can be distinctly observed in the phraseological units of the Spanish language. So, the evaluation of religious phraseological units of the Spanish language from the prism of new analysis of cognitive semantics suggests that native speakers enjoy the privilege of transmitting information through certain word-codes and very often there is a certain parallelism, more precisely, commonness with cognate languages, particularly, with the languages of peoples of the same religion.

The religious phraseological units have meanings different from their initial semantic capacity due to the semantic extension in the succeeding phrases, and these meanings are consistent with linguo-pragmatic condition of the media discourse in which a religious phraseological unit is practiced.

In the Spanish political, economic and media discourse, the religious phraseological units such as El Festín de Baltasar have gained additional connotations through semantic reassessment, and it is possible to conclude that this connotation has not only situational and contextual essence but also has acquired wide and general usage rather than occasional.
\end{abstract}

Keywords: the Spanish language, religious phraseological units, precedent onym, Balthazar's feast

\section{Inroduction}

It is known that the phraseological system of any language reflects the customs, traditions of the native speakers, their history, today's lifestyle, and also their future hopes and wishes by means of metaphoric coding. So, the expression of religious beliefs of this or that nation, and the ethical-moral codes which arise from these beliefs are quite logical. A nation in its spoken language, especially in its phrase-reflections (i.e., in the system of phraseological units used in connection with the definite situation or rituals), which are widely-used, uses its leading dogmas and also the plot and characters of their holy books: they are referred to, they are called, they are relied on, their friends are cursed by means of those religious characters or forces. The eternal loyalty of a man society to its history, customs-traditions, life-style (life standards) is undeniable, and taking it into consideration all this, we must admit that the Spanish language and its phraseological system are not exception in connection with the above-mentioned matters. So, in the phraseological system, the phraseological units with religious meaning in Spanish either from the point of view of their "weight", or from the point of view of their (the same religious phraseologisms) usage frequency in everyday life cannot sneak away from attention. Though a greater part of the religious phraseologisms in Spanish covers Bible citations and quasi-citation (which have been misinterpreted), Bible plot and characters' reminiscences, "reminders" make a certain part of them.

Together with it, there are not few expressions which refer to the reminiscences of characters' connected with local religious beliefs, and the expressions formed on the basis of the "reminiscences" (reminders) to the plots of 
Christian-catholic holies or their selfless and the long-suffering lifestyle the among religious phraseological units in Spanish.

\section{Research Methodology}

The methods used in any research should be appropriate to the topic investigated. The correct choice of methods guarantees the objective results of the investigation.

In the investigation process of the article connected with the religious phraseological units in the Spanish language, the following methods have been used: descriptive method, observation method, linguistic analysis method, diachronic method, synchronic method.

All the methods mentioned are used firstly to observe and then describe the subject of investigation, and besides, to approach the phenomenon in a detailed form and give its linguistic analysis.

\section{Lexical and Componential Analysis of Religious Phraseological Units in Spanish}

The lexical and componential analysis of religious phraseological units in the Spanish language makes it necessary to separately dwell on phrases with precedent onyms. Thus, "the cognitive science" that identifies the "nature" of modern linguistics, with its dynamically developing and many aspects, succeeded in "promoting the rapid development of the linguistic idea (Popova, 2007; Smirnitskiy, 1956) at the junction of centuries (XX and XXI centuries-R. A)" and introducing new concepts of analysis and research guidelines. It is known that cognition (from the Latin word "coqnitio") is a process of understanding, which covers the "processing and perception" of the information on the surrounding world acquired by the human being, and, in Kubryakova's terms, corresponds the concepts like "mental", "internal", "interiorized" (Note 1) (Kubryakova, 2004). The language aspect, especially the semantic aspect of cognitivism, namely, the mental identity of a native speaker can be distinctly observed in the phraseological units of the Spanish language. Thus, the evaluation of religious phraseological units of the Spanish language from the prism of new analysis of cognitive semantics suggests that native speakers enjoy the privilege of transmitting information through certain word-codes and very often there is a certain parallelism, more precisely, commonness with cognate languages, particularly, with the languages of peoples of the same religion. In this respect, the views of A. I. Smirnitsky, who defined that many expressions in English are distributed from "the ideological fund" common to cognate languages cannot but arouse interest (Smirnitskiy, 1956). For example, the perception of the Spanish phraseological units as fruto prohibido, hijo pródigo, Italian (frutto proibito, figliol prodigo), French (fruit défendu, enfant prodigue), English "forbidden fruit", "prodigal son", Russian (запретный плод, блудный сын) (Reunova, 2015) in an identical manner creates the necessity of establishing common idiomatic fund relating religious phraseological units, as well as following the manifestations of linguo-pragmatic and cognitive aspects in this context. It is worth considering the approach of Y. V. Reunova who comparatively investigated in her research paper linguo-pragmatic peculiarities of Biblicisms in Spanish, Russian, Italian and French with analogical semantic expressions. The linguist writes:

"The precedent phenomenon in common fields of research of cognitive linguistics and linguoculturology finds its reflection in different fields of knowledge (knowledge in a broad sense, namely, database on the real world - R. A) and is known for its universality and availability to wide human circle. The knowledge of precedent texts (including precedent onyms based on these texts- R. A) proves that the language personality belongs to specific period and relative linguoculture" (Carlos Sánchez, 2016). For example, the level of usage of phraseological units with precedent onyms in Spanish as el festín de Baltasar, el arca de Noé, el beso de Judas, llorar como una Magdalena (will be further discussed more widely) and others and the potential for the extension of its semantic burden gives us a ground to state that precedent texts and precedent onyms necessarily have "high recognition ratio" and display the ability to produce dynamic semantic extension (new meanings, connotations). It will suffice to pay attention to linguo-pragmatic and discursive peculiarities of religious phraseological units with precedent onyms in the following examples:

Es la Venezuela que profetizó el escritor Arturo Uslar Pietri, en su artículo "El festín de Baltasar", sobre el riesgo de depender tanto del petróleo y que ahora sufre por la caída de los precios del crudo, el cual representa el 96\% de sus ingresos. [http://www.el-nacional.com];

La revolución bolivariana y el festín de Balthazar. Si el liderazgo del comandante se ve comprometido, si acaso cesa el festín de Balthazar que ha caracterizado al chavismo durante estos catorce años.... [http://www.eluniversal.com].

Apparently, the religious phraseological unit in the aforementioned examples has a meaning which is different from its initial semantic capacity due to the semantic extension in the succeeding phrases, and this meaning is consistent with linguo-pragmatic condition of the media discourse in which a religious phraseological unit is 
practiced. Thus, as the media discourse implies the usage of the indirect meaning in this context, it has acquired a different pragmatic condition for the sarcastic characterization of the current political and economic situation. It is no coincidence that the cognitive semantics, a new area of linguistics, based on the observation of the same and similar semantic changes "has targeted the analysis of the knowledge and perceptions of the nonlinguistic reality reflected in language units of individuals sharing the same culture, as it is a new area of linguistics" (Cherneyko, 2015). One of the most interesting areas of research in cognitive semantics, as it is also evident from the preceding examples, appears to be the problem of precedent onyms and precedent texts in general.

A precedent text refers to texts (Latin praecedens (praecedentis) - “earlier", "preceding") known to both native speakers and to their predecessors in many ways (Kaprenko, 1998). Y. N. Karaulov, who has contributed the term "precedent text" to linguistics has grouped them as follows:

1) texts that are important for this or that person from the emotional viewpoint and data acquisition as well;

2) texts covering a wider circle of a person;

3) texts that are repeatedly applied within any given discourse (Karaulov, 2007).

In this respect, the texts referring to phraseological units with precedent onyms in Spanish can be attributed to the second group of texts. In other words, as is evident from the aforementioned examples, phraseological unit $\boldsymbol{e l}$ festín de Balthazar used in modern Spanish is primarily based on the precedent text of the "Bible". It should be noted that the precedent onym based on the "Bible", more precisely, the phraseological unit with proper name "Balthazar" appeared due to the carousal arranged by the Babylonian ruler of the same name.

It is known that "the principal factor shaping the precedent onym appears to be the existence of background knowledge which depends on the individual's cultural competence (skillfulness-R. A) and that precedent as well" (Krasnikh, 2002). Hence, we can say with certainty that the main point in the semantic and componential analysis of a religious phraseological unit is to define the degree of adequate acquisition by native Spanish speakers of the precedent onym, being its main component, i.e., to define the communicative-cognitive pragmatics.

\section{Discussions on the Topic}

Thus, the cognitive experimental studies in the most different languages allow to confidently identify the existence of a national cognitive base consisting of precedent phenomena, including precedent names in every language (Gudkov, 1998). What is the precedent onym "Balthazar" which bears no significance as a precedent phenomenon for ordinary Azerbaijani, Turkish, Persian, Arabic native speakers, but continues to be used and kept in the cognitive base of Spanish-speaking society for centuries and acquires new sub-meanings over time, and who is Balthazar in general? Balthazar is the son of Nabonidus and the last ruler of the Babylonian state who lived in the years 573-539 BC [Balthasar]. In fact, Balthazar, who ruled the state partially with his father Nabonidus, who had been on military trips for a long time, passed into the history as a negative image [Balthasar].

$\mathrm{He}$ "wrote his name" in the Bible with carousals that he arranged during the wars between his father (king Nabonidus) and the Cyrus II. (Lopukhin, 2000). "Old Testament" reads:

1). El rey Belsasar dio un gran banquete a mil de sus nobles, y en presencia de los mil se puso a beber vino (Julian Borger, 2016).

2). Mientras saboreaba el vino, Belsasar ordenó traer los vasos de oro y plata que Nabucodonosor su padre habia sacado del templo que estaba en Jerusalén, para que bebieran en ellos el rey y sus nobles, sus mujeres y sus concubinas" (Daniel 5:1-2) (Daniel 5).

As is known, overindulged in carousals, Balthazar had brought gold and silver flatware kept in Jerusalem temple to be used in his feasts which could be a great sin in terms of their sanctity. As "Old Testament" reads, in the course of this feast Balthazar was warned about the revenge for this unprecedented humiliation and a short warning text was drawn on the walls of the palace where the feast was held. $25 \mathrm{Y}$ ésta es la inscripción que fue trazada: MENE, MENE, TEKEL, UFARSIN. 26 Esta es la interpretación del escrito: MENE: Dios ha contado tu reino y le ha puesto fin. 27 TEKEL: has sido pesado en la balanza y hallado falto de peso. 28 PERES: tu reino ha sido dividido y entregado a los medos y persas. (Daniel 5). For this reason el festín de Balthazar (Balthazar's feast) began to express an indirect meaning, namely, "to irresponsibly overindulge oneself before terrible tragedy without thinking of tomorrow and realizing the danger [Balthazar feast]. Hence, Balthazar was killed the next morning, immediately after his own carousal. 
"Entonces Belsasar ordenó que vistieran a Daniel de púrpura y le pusieran un collar de oro al cuello, y que proclamaran acerca de él, que él tenía ahora autoridad como tercero en el reino. 30 Aquella misma noche fue asesinado Belsasar, rey de los caldeos" (Reunova, 2015).

Interestingly, this religious phraseological unit has been used even in the field of psychological terminology, as well as in the meaning of "luxurious life of asocial people even in public grief and sorrow, also regressive behavior without being aware of anticipated distress" (Balthazar feast).

In modern Spanish, all the connotations of this phraseological unit demonstrate a high frequency of usage.

Es raro el caso que un dictador que ha visto "la mano escribir sobre el muro" como en el Festín de Baltasar, no haga febriles esfuerzos para escapar la furia de un pueblo [http://www.elsalvador.com].

Apparently, the precedent onym Balthazar in the aforementioned passage is considered as a generalized image of dictators. In the following example, Balthazar's feast is recalled in the context of political processes in Spain:

Hasta aqui el festín de Baltasar y las palabras del profeta. Ya de vuelta a España, medos y persas andan al acecho, ya no ocultan sus pretensiones de dividir el Reino (http://blogs.culturamas.es).

The following example particularly "hints" the four-word threats drawn on the wall in the course of Balthazar's feast rather than the use of the phraseological unit with precedent onym.

Tres palabras, sonoras como bofetadas bastan: entre ellos todo se reduce a "Pinsk, Minsk y Dvinsk"/ (Balthazar feast).

Este refrán pesa, mide y separa como la mano en el festín de Baltasar. Sus estudiantes se ponen en huelga para lograr que los ingleses le despidan [http://carlossalgadodp.blogspot].

In contrast to the languages of other related peoples who practice Christianity, the semantic development of the religious phraseological unit el festín de Baltasar in Spanish visually asserts J. Derrida's views-"Since the language is the basis of existence, the world itself embodies an endless text (Derrida Jacques, 1986)". Accordingly, the fact that the expression el festín de Baltasar can make a different precedent text in the different context helps to understand the underlying meaning of the idea "Any text contains more information than it appears at first glance" (Krasnikh, 2002) by J.Derrida who also put forward the idea that the world, the history themselves, in fact, consist of texts. The question is about socio-economic or ethnic stereotyping that emerges on the initial semantic capacity at the stage succeeding bible-based textual allusion. The growing interest in such kinds of stereotyping in linguistics in recent years, as A.Koroleva noted, is conditioned by the fact that ethnic and socio-economic stereotypes were selected as a research object not only by ethno psychology, ethnopsycolinguistics but also by cognitive linguistics (Koroleva, 2011). Here are some examples:

En "El Festín de Baltasar", Arturo Uslar Pietri trata principalmente, haciendo analogía con el pasaje bíblico que tiene ese nombre, del despilfarro excesivo que han realizado los gobiernos posteriores a ese golpe que tanto le duele a Uslar de 1945. [http://www.diariodelosandes.com]

En su artículo "El festín de Baltasar", Uslar Pietri menciona el episodio bíblico del festín del rey Baltasar, cuando Daniel tiene que descifrar las palabras escritas en el muro del palacio [http://www.larazon.net/2015/].

It seems that in the format of textual allusions formed on the basis of political and economic problems of the Latin American countries, phraseological unit El festín de Baltasar demonstrates adequate genetic affiliation with the Bible, along with intertextual affiliation with the article of Arturo Uslar Pietrí with the same name. It should be noted that according to Y. Kristeva, the founder of the theory of intertextuality, this concept (i.e, intertextuality) - contains "permutation of texts" (substitution, change) (Poveryeva, 2012). In other words, a text acquires a different text format in another context, or the Biblical text, being the allusive background of phraseological units with precedent onyms as El festín de Baltasar makes up a dual textual matrix which is used in other contexts, in other words, in the title of the article. In the first case, a religious phraseological unit is considered to contain a precedent onym due to the historical-mythological context of the person's name, Balthazar. In the second case, the religious phraseological unit El festin de Baltasar itself embodies the whole precedent onym, for it already forms precedent phenomenon as an article component, and here the Balthazar component recedes into the background. It is of great interest to consider the approach of N.V.Petrova who stated that "the main postulate of the semiotic theory of culture is the recognition of culture as a system of signs". The linguist draws attention to the idea that "every culture is a system of conventional (conditional- $\mathrm{R}$. A) system of signs" (Petrova, 2010). 
Venezuela, desde el petróleo, y aún, vive en un festín de Baltasar, un festín de Baltasar que es financiado por la bonanza petrolera. Así nos lo dice el autor: "El Estado financia todo este artificioso mecanismo, y al Estado lo financia el petróleo." (p. 24) en "El Festín de Baltasar" [http://www.diariodelosandes.com] .

In the example quoted from the same context we find out that the expression El Festín de Baltasar is used as a religious phraeological unit with precedent onym (vive en un festín de Baltasar, un festín de Baltasar que es financiado por la bonanza petrolera). We also notice that the expression El Festín de Baltasar is referred to as a precedent onym (see p. 24) "El Festín de Baltasar").

Though it goes beyond the topic, it is worth mentioning that the article "El Festín de Baltasar", which had not lost its relevance to the political-economic situation of Latin American countries, was written on July 14, 1936. In fact, Arturo Uslar Pietri (1906-2001), the author of this article, whose original name was Sembrar el petróleo, was a writer, lawyer and political figure, one of Venezuela's most brilliant intellectuals (Arturo Uslar Pietri). In his well-known article that expressed his concern about the dependence of his country on oil revenues, he emphasizes that the government is in a festive mood inspired by the magic of wealth (Gustavo Luis Carrera) and reminds its political opponents of the terrible consequences of the Balthazar's feast in the Biblical narrative (see more: (Luis Xavier Grisanti)). From this context, we can conclude that in the Spanish political-economic and media discourses, the phraseological unit El Festín de Baltasar can express a derived meaning in its subsequent stage, except its original metaphorical meaning. This is followed by a precedent phenomenon "text in the text" effect which in turn, visually proves the remarkable scholar in the field of semiology Y. M. Lotman's idea:

"Culture can be viewed as a whole text. But it is of exceptional importance to emphasize that the text is in fact, a compact text that can be divided into textual hierarchy within texts" (Lotman, 1992). A striking example of the textual hierarchy is shown below.

Venezuela sigue en Festín de Baltasar y, como menciona Uslar en dicha obra, durará "hasta que dure el auge de la explotación petrolera" (p. 25), sin embargo me niego a hundirme en las "profecías apocalípticas", por decirlo de alguna forma, de Uslar Pietri [http://www.larazon.net/2015].

In the Spanish political, economic and media discourse, the religious phraseological unit El Festín de Baltasar has gained additional connotations through semantic reassessment, and there are quite objective reasons to conclude that this connotation has not only situational and contextual essence but also has acquired wide and general usage rather than occasional. Hence, oil dependence of Venezuela, economically one of the most unstable and politically the most controversial states in Latin America, has enabled the religious phraseological unit El Festín de Baltasar to get a new connotation against the background of Usler Pietry's revealing article. It is known that the annual income of Venezuela per capita, which had been dependent on oil revenues since 1926, enabled it to gain leading positions among Latin American countries [Economy of Venezuela]. From the 20s to the $60 \mathrm{~s}$ of the twentieth century, $90 \%$ of Venezuela's export revenues were derived from only oil sales [Economy of Venezuela]. Therefore, as the oil prices in the world market fell, Venezuela became the global leader with the inflation rate of $180 \%$ [Yolanda Valeri] which proved that the terrible presumptions (Note 2) of Uslar Pietry expressed in his article was a bitter reality. In contemporary texts, we observe the frequent usage of the additional connotation of the same religious phraseological unit.

Pero nada que le importe al gobierno de Guyana, pais que, al igual que sus socios en el Caricom (comunidad de países angloparlantes del Caribe) también participó en el festín de Baltasar de las riquezas Venezuela, nación cuyo presidente, David Granger, realiza una diplomacia agresiva en torno al Esequibo y dice en privado que le va a ver el hueso a Maduro y su revolución. [http://hortaroja.com/?p=1504].

The fact that dependence on oil brought to misery and hunger in Venezuela in the XXI century, its "most serious crisis throughout the history" (Smirnitskiy, 1956) and the largest budget deficit (Carlos Sánchez, 2016) allowed the authors to accuse senior officials of the failure to anticipate possible calamity as carelessly as Balthazar did, when Venezuela had abundant oil revenues at one time.

Tras la dolorosa partida de nuestro Líder Eterno, el Comandante Chávez nuestro pueblo se debilita cada vez más, sumergido como está en el Festín de Baltasar, "izquierdosos endógenos de cafetín", "comunistas lichts" y "boliburgueses, rojo-rojitos" (León Moraria).

The reference to the famous religious phraseological unit with precedent onym Balthazar to describe such a difficult and tragic situation even at country scales clearly demonstrates the truthfulness of Y. A. Nahimova's findings, who investigated the cognitive-discursive and linguo-pragmatic peculiarities of precedent onyms in the media discourse. The researcher writes: 
"Precedent onym is a kind of standard which serves as a basis for the evaluation of this or that behavior, as well as a canon for taking examples" (Nakhimova, 2011). In the example of the religious phraseological unit $\boldsymbol{E} \boldsymbol{l}$ Festín de Baltasar, we can notice that the precedent onym Balthazar is used as a criterion for measuring the serious consequences of irresponsible behavior, his good-for-nothing decisions, without thinking of tomorrow.

Con el calificativo, "festín de Balthazar" se ha designado el uso que de las divisas del petróleo han hecho los gobiernos .... El festín de Balthazar, una vez más sirvió para alimentar el desquiciamiento del gobierno de Chávez (Tatiana, 2014).

In view of the fact that the religious phraseological unit El Festín de Baltasar can be found in the precedent phenomenon base of Spanish-speaking society with both its initial and derived meanings, the article "Sembrar el petróleo" by Arturo Uslar Pietri received two nominations thanks to the phraseological unit spoken about in Spanish media discourse and generally, in Spanish-speaking society.

Su política social se centra en la necesidad del "combate fecundo con el minotauro del petróleo", del cual depende el presente y el futuro de esta "Venezuela pobre", ciega por el "Realismo Mágico" que se ahoga en el "Festín de Balthazar" (Tatiana, 2014).

Evidently, the first case involves the precedence of the person's name, and the second case, namely, the second-level precedence, involves the precedence of the article title.

\section{Concluding Remarks}

The given analyses give the opportunity of arriving at a conclusion in connection with the role of precedent onyms factor in religious phraseological units in the Spanish language. It becomes known that in Spanish, together with Bible citation and quasi-citations, religious characters have the potential of creating strong phraseological units. It is an interesting fact that together with the main Bible characters, peripheral characters like Balthazar gave force to the formation of the expressions which continue to be used in Modern Spanish phraseology. Another interesting matter is that in the framework of Spanish phraseology and especially in the given article, the expressions with precedent onyms, which we dealt with, again are able to get semantic evaluation in the next stage. As a concrete matter, on the face of phraseological unit with precedent onyms $E l$ festin de Baltasar, we witness the Spanish religious phraseologisms to get the permutation of texts, obtaining a new and more different semantic meaning as a result of diferent social-political contexts. There is no argument that the semantic shades, which are acquired newly, though they cannot vanish initial semantic content with Bible reference, give it a new meaning. In this case, we have proved that a phraseological unit with inital religious content prevails its semantic borders and "are able to become private" in different discoursive conditions. And this, mainly, denotes that Spanish phraseological system, especially, Spanish religious phraseolgy has "deft" content, and it shows that Spanish religious phraseolgy has the potential of expressing the wishes and intention, the fear and excitement of the nation in a good way-in a laconic and meaningful metaphoric manner, "feeling the pulse" of the modern life of the community consisting of native speakers.

In the article, the evatuations around the target problem have given us an opportunity to follow the emphasis of one main moment connected with Spanish phraseology. Thus, the spread of Spanish in a vast geographic areal makes it possible to enlarge its lexic and phraseological system with a dynamic development, in different parts and continets of the world. Though the spanish-speaking community has a shared idiomatic fund, this fund goes on enlarging in different directions, on the basis of different historic-social and linguo-cultural reality.

Taking as an example the precedent onyms El festín de Baltasar phraseological unit, we observed the fact that new meaning evatuation, which based on Latin America realities, was included in joint Spanish idiomatic fund. In its turn, it give us the possibility to say that spanish-spaeking community settled in different geographical areals forms a language environmet, which demonstrates enough conservativism to save its organic relationship. And not depending on the geographical area where the spaekers of this langauge live, it doesn't lose its historic ties and jointness.

Another important moment showing the conservativism, in the positive meaning, of spanish-spaeking community is connected with the loyal approach to religious-historic belongings, which is one of the main factors forming etno-cultural "identity" of language-speakers. The talk here is about the loyalty of spanish-speaking community to their ancient christian traditions and making this inheritance survive brilliantly in their religious content phraseology. So, spanish-spaeking community prefer to name modern socio-historical reality, social-political, economic cataclisms and challenges, which took place in XX c and passed to XXI c, with "metaphorically encoded" examples, living in their historical memory.

It is doubtless that the ability "to build a bridge" between history and modernity, shows the might of 
spanish-spaeking community and the profound respect to their own language, history and national identity.

\section{References}

Arturo Uslar Pietri. (n. d.). Retrieved from https://es.wikipedia.org/wiki/Arturo_Uslar_Pietri

Balthasar of Babylon. (n. d.). Retrieved from https://es.wikipedia.org/wiki/Baltasar_de_Babilonia

Balthasar, prince of Babylon. (n. d.). Retrieved from http://www.mcnbiografias.com/app-bio/do/show?key=baltasar1

Balthazar feast. Encyclopedic Dictionary of expressions. (2003). Moscow, "Lokid- Press", Vadim Serov. Retrieved from http://dic.academic.ru/dic.nsf/dic_wingwords/335/\%D0\%92\%D0\%B0\%D0\%BB $\%$ D $1 \% 82 \% \mathrm{D} 0 \% \mathrm{~B} 0 \% \mathrm{D} 1 \%$ $81 \% \mathrm{D} 0 \% \mathrm{~B} 0 \% \mathrm{D} 1 \% 80 \% \mathrm{D} 0 \% \mathrm{BE} \% \mathrm{D} 0 \% \mathrm{~B} 2$

Balthazar feast. Encyclopedic Dictionary of Psychology and Pedagogy. (2013). Retrieved from http://psychology_pedagogy.academic.ru/3375/\%D0\%92\%D0\%B0\%D0\%BB $\% \mathrm{D} 1 \% 82 \% \mathrm{D} 0 \% \mathrm{~B} 0 \% \mathrm{D} 1 \% 81$ $\% \mathrm{D} 0 \% \mathrm{~B} 0 \% \mathrm{D} 1 \% 80 \% \mathrm{D} 0 \% \mathrm{BE} \%$

Carlos, S. (2016). Venezuela: the (economic) farce ends in tragedy. Retrieved from http://www.elconfidencial.com/economia/2016-05-17/venezuela-chavismo-economia-crisis-petroleo_12010 $19 /$

Cherneyko, L. O. (2015). Cognitive semantics (word in language and speech). (n. d.). Retrieved from http://www.philol.msu.ru/data/ magistracy/fca/016.pdf

Daniel 5. (n. d.). Retrieved from http://bibliaparalela.com/lbla/daniel/5.htm

Derrida, J. (1986). Difference in: Critical Theory since 1965 (pp. 83-94). Gainesville, Florida: University Press of Florida.

Economy of Venezuela. (n. d.). Retrieved from https://en.wikipedia.org/wiki/Economy_of_Venezuela

Economy of Venezuela. (n. d.). Retrieved from https://es.wikipedia.org/wiki/Econom\%C3\%ADa_de_Venezuela

Gudkov, D. B. (1998). A precedent onym in the cognitive basis of the modern Russian language (results of the experiment). The language, consciousness, communication (Philology, Moscow, pp. 82-93). Retrieved from http://www.philol.msu.ru/ slavphil/books/jsk_04_05gudkov.pdf

Gustavo Luis Carrera. (n. d.). Retrieved from The oil novel in Venezuela http://www.saber.ula.ve/bitstream/123456789/15838/2/ novela_petroleo.pdf

http://blogs.culturamas.es/oscarmprieto/2013/09/24/mane-thecel-phares/

http://carlossalgadodp.blogspot.com/2016/01/ensayo-critico-de-el-festin-de-baltasar.html

http://hortaroja.com/?p=1504

http://www.diariodelosandes.com/index.php?r=site/noticiasecundaria\&id=22085

http://www.el-nacional.com/GDA/bEl-Comerciob-Venezuela-caos-esperanza_0_885511453.html

http://www.elsalvador.com/articulo/la-nota-del-dia/busca-maduro-quienes-ayuden-escapar-130043

http://www.eluniversal.com/opinion/121216/la-revolucion-bolivariana-y-el-festin-de-baltazar

http://www.larazon.net/2015/07/26/sin-petrodolares-maduro-es-un-dictador-bananero-del-monton/

Julian, B. (2016). Venezuela's worsening economic crisis-the Guardian briefing. The Guardian, 22 June. Retrieved

from https://www.theguardian.com/world/2016/jun/22/venezuela-economic-crisis-guardian-briefing

Kaprenko, L. A., Petrovskiy, A. V., \& Yaroshevskiy, M. G. (1998). Interiorization//Brief psychological dictionary. Rostov-na-Donu: "FENIX".

Karaulov, Y. N. (2007). The Russian languages and linguistic identity (Moscow, published by LKI, p. 264).

Koroleva, Y. A. (2011). Methods for establishing the content of an ethnic stereotype (on a material of the Spanish language) (pp. 324-327). Bulletin of the Chuvash University, edition No 2. Retrieved from http://cyberleninka.ru/article/n/sposoby-ustanovleniya-soderzhaniya-etnicheskogo-stereotipa-na-materiale-i spanskogo-yazyka

Krasnikh, V. V. (2002). Ethnopsycholinguistics and linguoculturology. The lecture course of Krasnikh V. V., 
Moscowm ITDGK “Gnosis”, p. 284.

Kubryakova, E. S. (2004). About cognitive science and topical problems of cognitive linguistics. Problems of cognitive linguistics, No. 1, pp. 6-17.

León, M. (n. d.). Baltasar's feast and oil renaissance. Retrieved from http://www.aporrea.org/actualidad/a222127.html

Lopukhin, A. P. (2000). The King Balthazar//Orthodox Theological Encyclopedia. Published by the Church Research Center "Orthodox Encyclopedia". Retrieved from http://www.biblioteka3.ru/biblioteka/pravoslavnaja-bogoslovskaja-jenciklopedija/tom-3/valtasar-car.html

Lotman, Y. M. (1992). Culture and Explosion (p. 272). Moscow, Gnosis, Progress Publishing Group.

Luis, X. G. (n. $\quad$ d.) Sow oil or sow citizens? Retrieved from http://www.petroleoyv.com/website/uploads/grisanti_5.pdf

Nakhimova, E. A. (2011). Precedent onyms in modern Russian mass communication: theory and methodology of cognitive-discursive research. monograph, Yekaterinburg, GOU VPO "Ural: ГОУ ВПО "Ural State Pedagogical University", p. 313.

Petrova, N. V. (2010). The evolution of the concept of "precedent text". Bulletin of the Irkutsk State Linguistic $\begin{array}{llllll}\text { University, } & \text { No. } & 2, & \text { pp. } & \text { 177-182. } & \text { Retrieved }\end{array}$ http://cyberleninka.ru/article/n/evolyutsiya-ponyatiya-pretsedentnyy-tekst

Pietri, A. U. (n. d.). Nine years after his death. continues with his phrase: "Sow the oil". Retrieved from $\mathrm{http}: / /$ www.notiactual.com/a-nueve-anos-de-su-muerte-arturo-uslar-pietri-sigue-vigente-con-su-frase-\%E2 $\% 80 \% 9$ Csembrar -el-petroleo\%E2\% 80\%9D/

Popova, Z. D., \& Sternin, I. A. (2007). Cognitive Linguistics (p. 315). Moscow, AST: Vostok-Zapad.

Poveryeva, E. V. (2012). Problems of the theories of intertextuality in modern linguistics. International Journal of Applied and Fundamental Research, 39-44. Retrieved from http://cyberleninka.ru/article/n/problemy-teoriy-intertekstualnosti-v-sovremennom-yazykoznanii

Reunova, E. V. (2015). Linguo-pragmatic analysis of bibleisms in Russian, Spanish, Italian, French and English languages, the dissertation abstracts ...... candidate of Philology (p. 23). Moscow.

Smirnitskiy, A. I. (1956). Lexicology of the English language (p. 220). In V. V. Passeka (Ed.). Moscow, the publishing house of literature in a foreign language.

Tatiana B. de Maekelt Panegyric of the doctor Arturo Uslar Pietri. (2004). Bulletin of the Academy of Political and Social Sciences/Academy of Political and Social Sciences, Caracas, No. 142. Retrieved from http://acienpol.msinfo. info/bases/biblo/texto/boletin/2004/BolACPS_2004_142_11-24.pdf

The precedent. The new dictionary of methodological terms and concepts (the theory and practice of teaching languages). (2009). Moscow, the publishing house IKAR. E. G. Azimov, A. N. Shukin, Retrieved from http://methodological_terms.academic.ru/1449/\%D0\%9F\%D0\%A0\%D0\%95\%D0\%A6\%D0\%95\%D0\%94 \%D0\%95\%D0\%9D\%D0\%A2\%D0\%9D\%D0\%AB\%D0\%99

Yolanda, V. (2016). Venezuela: the country is on the verge of collapse. Retrieved from http://www.bbc.com/russian/international/ 2016/05/160518_venezuela_food_crisis

\section{Notes}

Note 1. İnteriorization (in French, "to enter from the outside") means the "formation of the internal structure of human psycology through the adoption of external social activity" (Balthazar feast, 2013)

Note 2. ¿Hasta cuándo podrá durar este festín? (With the allusion to Baltazar's feast.) Hasta que dure el auge de la explotación petrolera. El día en que ella disminuya o decaiga, si continuamos en las condiciones actuales, habrá sonado para Venezuela el momento de una de las más pavorosas catástrofes económicas y sociales..... Hasta que aquella mano misteriosa escribe en la pared la enigmática sentencia que anuncia la inevitable catástrofe y que empieza con la palabra "mene" (With the allusion to the warning text drawn on the wall during Baltazar's feast- R. A). Una palabra que las gentes del lago de Maracaibo conocen bien y saben descifrar (Luis Xavier Grisanti). 


\section{Copyrights}

Copyright for this article is retained by the author(s), with first publication rights granted to the journal.

This is an open-access article distributed under the terms and conditions of the Creative Commons Attribution license (http://creativecommons.org/licenses/by/4.0/). 